\title{
APPLICATION OF LANDSAT SATELLITE IMAGES FOR RESEARCH ON CHANGES OF VEGETATION CONDITIONS IN THE "BAGNO CHLEBOWO" NATURA 2000 SITE
}

\author{
Paweł Czyż $\dot{z}^{1 凶}$, Anna Kowalik², Paweł Rutkowski² \\ ${ }^{1}$ Pisz Forest Division \\ Gdańska 24, 12-200 Pisz, Poland \\ ${ }^{2}$ Department of Forest Sites and Ecology, Poznań University of Life Sciences \\ Wojska Polskiego 71F, 60-625 Poznań, Poland
}

\begin{abstract}
On the basis of the analysis of Landsat 7 and 8 satellite images, compared to field researches, differentiation of plant cover of "Bagno Chlebowo" Natura 2000 Site was shown. Vegetation indices NDVI, RVI, the content of chlorophyll "a" in the water, changes of vegetation cover in infrared and natural colour compositions were taken into the consideration.
\end{abstract}

Key words: NDVI, RVI, chlorophyll "a”, remote sensing

\section{INTRODUCTION}

The range of visible light makes a slight percentage of electromagnetic radiation reaching the Earth. Utilization of radiation from the scope of near and far infrared reflected and absorbed by plants constitutes the basis for remote sensing research of vegetation (e.g. Campbell and Wynne, 2011; Jones and Vaughan, 2010; Wiśniewska, 2013). To that purpose remote sensing uses images from aircrafts, from the ground and satellite images. Over 40 years have passed since the moment the first Landsat satellites were put into the circumterrestrial orbit (23 July 1972). Satellites of this series were intended from the very beginning to monitor changes of the environment because of making images both in visible light and in multispectral bands. Their usefulness also results from general data availability and a long operation period, whereby they are perfectly suitable for tracking changes that undergo in nature (e.g. Ostapowicz, 2012; Piekarski and
Zwoliński, 2012). The aim of the study was to check these possibilities in research on changes of vegetation undergoing in the "Bagno Chlebowo" Natura 2000 site at the base of satellite images generated from satellites Landsat 7 and Landsat.

\section{RESEARCH AREA}

The "Bagno Chlebowo" Natura 2000 site (PLH 300016) is situated in the catchment of the Ludomicki Canal, ca. $10 \mathrm{~km}$ long, that flows through the Kończak Canal into the Warta River near the village of Stobnica (Fig. 1). The area is situated between 52 $44^{\prime} 41.82^{\prime \prime}$ and $52^{\circ} 43^{\prime} 41.41^{\prime \prime}$ of north latitude and $16^{\circ} 44^{\prime} 18.73^{\prime \prime}$ and $16^{\circ} 46^{\prime} 20.92^{\prime \prime}$ of east longitude. A significant part of the total area of 465.31 (SDF, 2013) is occupied by peat bogs, surrounded by vast chains of dunes from the north, west and south, overgrown with pine coniferous

®czyzpw@poczta.onet.pl 
Czyż, P., Kowalik, A., Rutkowski, P. (2016). Application of Landsat satellite images for research on changes of vegetation conditions in the "Bagno Chlebowo" Natura 2000 site. Acta Sci. Pol. Silv. Colendar. Ratio Ind. Lignar., 15(3), 145-160. DOI: 10.17306/J. AFW.2016.3.17

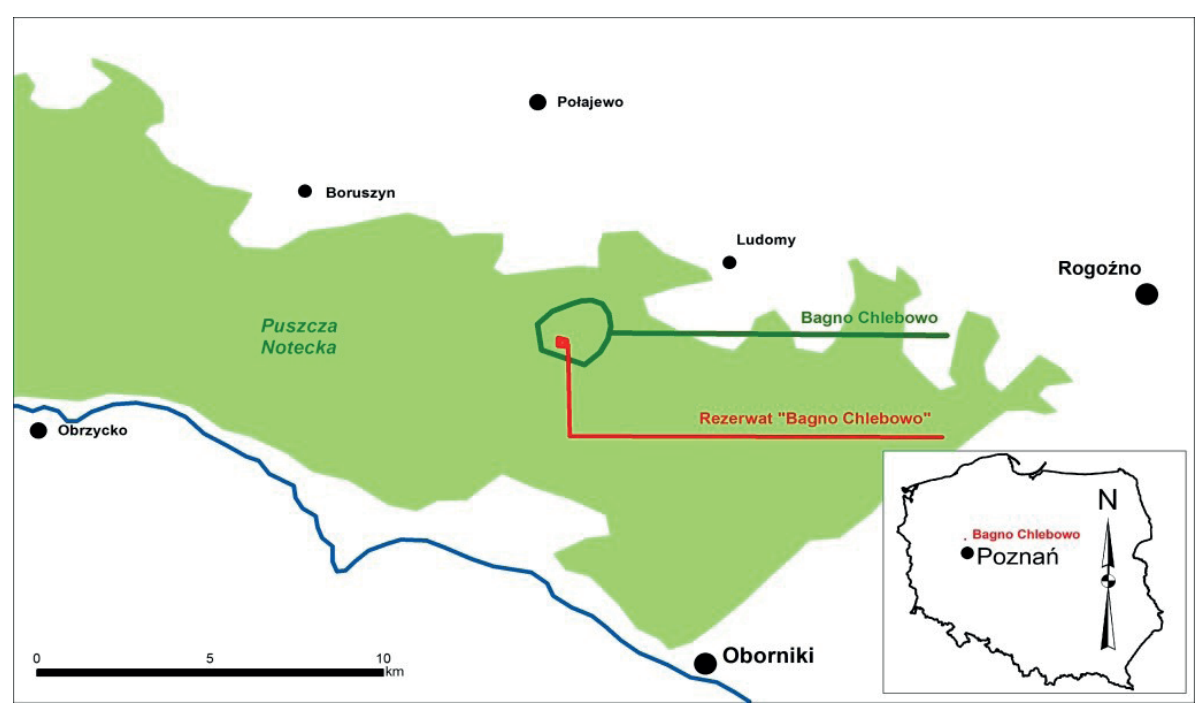

Fig. 1. Location of the "Bagno Chlebowo" Natura 2000 site (dark green frame) and nature reserve "Bagno Chlebowo" (red dot) at the base of the Notecka Primeval Forest (light green area)

Rys. 1. Lokalizacja obszaru Natura 2000 „Bagno Chlebowo” (ciemnozielona otoczka) i rezerwatu przyrody „Bagno Chlebowo” (czerwony punkt) na tle Puszczy Noteckiej (obszar jasnozielony)

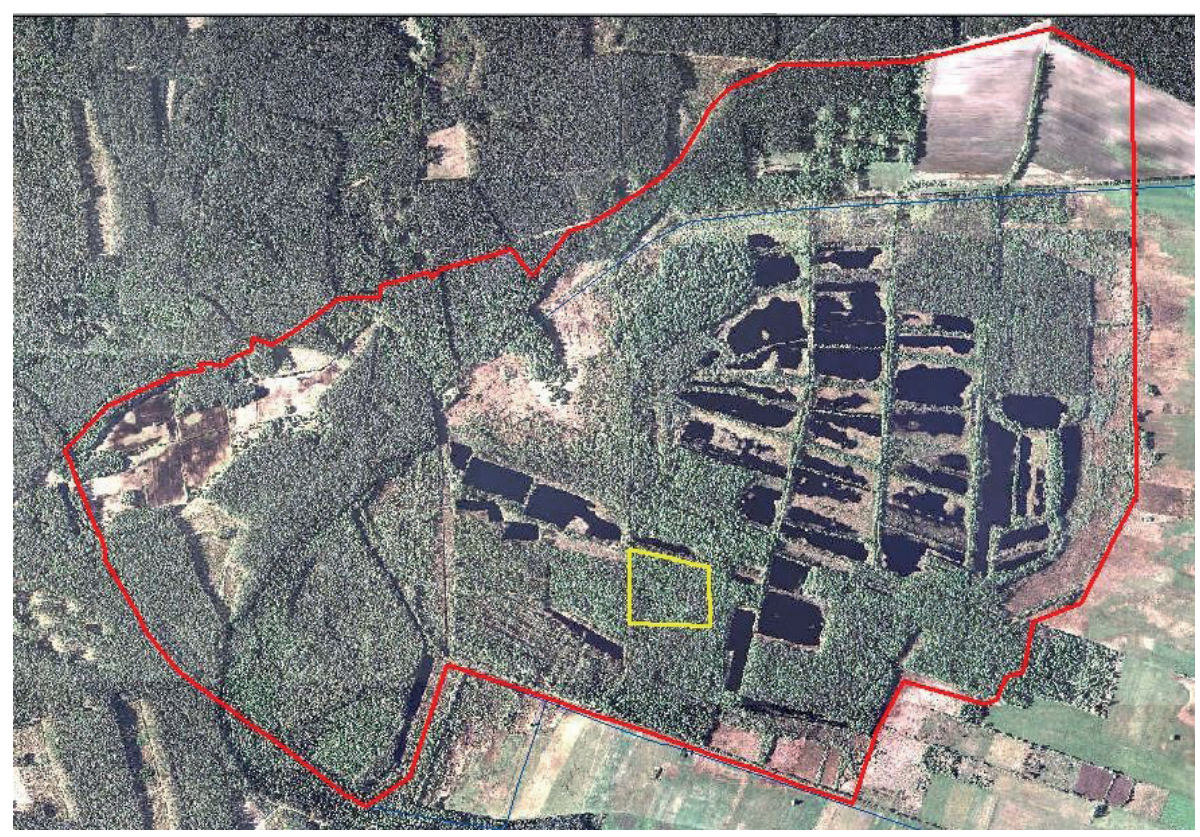

Fig. 2. Satellite image of the "Bagno Chlebowo" Natura 2000 site (red frame) and nature reserve (yellow frame) with noticeable open water tables (Apis, 2012)

Rys. 2. Obraz satelitarny obszaru „Bagna Chlebowo” (czerwona obwódka) i rezerwatu przyrody (żółta ramka) z widocznymi otwartymi lustrami wody (Apis, 2012) 
forests, that constitute the eastern edge of the Notecka Primeval Forest.

The analysis of historical data points to the continuing process of peat digging in this area (Wełnicka et al., 2015), which took on an industrial character after the end of the Second World War. The effects of peat digging are the open water tables in pits where peat was dug, noticeable until now (Fig. 2).

An attempt to protect the most valuable parts of the peat bog was establishing in 1959, by decision of the Minister of Forestry and Timber Industry, the nature reserve "Bagno Chlebowo", with a surface area of 4.42 ha, that constitutes approximately $1 \%$ of the present Natura 2000 site under the same name.

\section{MATERIAL AND METHODS}

For analyses the available free images from satellites Landsat 7 and Landsat 8 were used (http 2015a, http 2015b, http 2015c). The images were made in resolution $30 \times 30 \mathrm{~m}$ and such value was assumed for calculations for statistical purposes. The analyses were carried out with Open Source software: QGIS version 2.12.2 Lyon with free plug: Semi-Automatic Classification Plugin. The images were subjected to atmospheric correction using DOS1 algorithm in the pre-processing process, pan-sharpened and converted from $\mathrm{K}$ degrees to $\mathrm{C}$ degrees for thermal images.

Owing to the high number of vegetation indices applied in remote sensing, the analysis was focused on the most frequently applied indices, i.e. NDVI (Normalized Difference Vegetation Index) and RVI (Ratio Vegetation Index).

NDVI index is used to quantify the photosynthetic capacity of plant canopies and

forecasting of yield crop and biomass production. It also provides information on changes in chlorophyll content, as well as information on water stress plants.

For calculation of the NDVI index the following formula was applied (http, 2015c):

$$
\begin{gathered}
\text { NDVI }=(\mathrm{B} 4-\mathrm{B} 3) /(\mathrm{B} 4+\mathrm{B} 3) \text { for Landsat } 7 \mathrm{TM} \\
\mathrm{NDVI}=(\mathrm{TM} 5-\mathrm{TM} 4) /(\mathrm{TM} 5+\mathrm{TM} 4) \text { for Landsat } 8
\end{gathered}
$$

Index RVI, recommended, among others, by Wiśniewska (2013) was used too. RVI, commonly known as a Vegetative Index, exceeding the value of 1 for the naked earth cover, and over 20 for very dense vegetation cover.

For RVI the following formula was used (http, 2015c):

$$
\begin{gathered}
\mathrm{RVI}=\mathrm{B} 4 / \mathrm{B} 3 \text { for Landsat } \mathrm{TM} \\
\mathrm{RVI}=\mathrm{TM} 5 / \mathrm{TM} 4 \text { for Landsat } 8
\end{gathered}
$$

where:

B3, B4 - spectral channels of Landsat 7 satellite, TM4, TM5 - spectral channels of Landsat satellite 8.

Also the composition of infrared channels was submitted to analysis (B4, B3, B22 for Landsat 7 and TM5, TM4, TM3 for Landsat 8) and images in visible light from 1975 to 2014.

The content of chlorophyll "a" in the water was also analysed based on the available images. Ghezzi et al. (1998) found that in case of LANDSAT TM data the spectral reflection in TM3 range can be subtracted from the spectral reflection in TM2 channel in order to adjust the influence of radiation dispersion by inorganic particles suspended in water. Following this line of thought they obtained the following form of dependence with the determination coefficient $\mathrm{R}^{2}=0.738$ :

$$
\begin{gathered}
\mathrm{Chl}-\mathrm{a}\left[\mathrm{mg} / \mathrm{m}^{3}\right]=40.741 \cdot\left[\left(\rho \mathrm{TM} 2^{\mathrm{atm}}-\rho \mathrm{TM} 3^{\mathrm{atm}}\right) /\right. \\
\left.\rho \mathrm{TM} 1^{\mathrm{atm}}\right]
\end{gathered}
$$

where:

$\rho \mathrm{TM} 1^{\mathrm{atm}}, \rho \mathrm{TM} 2^{\mathrm{atm}}, \rho \mathrm{TM} 3^{\text {atm }}-$ spectral reflection in TM1, TM2 and TM3 channels, adjusted because of the influence of the atmosphere.

Results of field studies carried out by the company Apis (2015) were adopted as reference point between the images and the condition on the ground.

\section{RESULTS}

\section{Analysis of NDVI index}

In total, for the winter period (January 2015) and summer (September 2014 and July, August and September 2015), for the area covered by the image shown in Figure 3, NDVI index values ranging from -0.715 to 0.925 have been shown. These values coincide with both minimum and maximum for the summer season. In winter range was narrower (from -0.089 to 0.795 ), 
Czyż, P., Kowalik, A., Rutkowski, P. (2016). Application of Landsat satellite images for research on changes of vegetation conditions in the "Bagno Chlebowo" Natura 2000 site. Acta Sci. Pol. Silv. Colendar. Ratio Ind. Lignar., 15(3), 145-160. DOI: 10.17306/J. AFW.2016.3.17

Table 1. Analysis results of NDVI coefficient for studied images

Tabela 1. Wyniki analizy współczynnika NDVI dla badanych zobrazowań

\begin{tabular}{lccccc}
\hline \multirow{2}{*}{ Value - Wartość } & \multicolumn{5}{c}{ Image of - Zobrazowanie z dnia } \\
\cline { 2 - 5 } & $2014-09-16$ & $2015-01-06$ & $2015-07-01$ & $2015-08-02$ & $2015-09-19$ \\
\hline $\begin{array}{l}\text { Minimal value } \\
\text { Wartość minimalna }\end{array}$ & 0.011 & -0.089 & -0.578 & -0.262 & -0.715 \\
$\begin{array}{l}\text { Maximal value } \\
\text { Wartość maksymalna }\end{array}$ & 0.848 & 0.795 & 0.925 & 0.924 & 0.881 \\
$\begin{array}{l}\text { Mean value } \\
\text { Średnia wartość }\end{array}$ & 0.686 & 0.579 & 0.743 & 0.770 & 0.695 \\
$\begin{array}{l}\text { Standard deviation } \\
\text { Odchylenie standardowe }\end{array}$ & 0.094 & 0.159 & 0.101 & 0.115 & 0.130 \\
$\begin{array}{l}\text { Pixel size } X \text {, m } \\
\text { Rozmiar piksela } X \text {, m }\end{array}$ & 29.992 & 29.992 & 29.992 & 29.992 & 29.992 \\
$\begin{array}{l}\text { Pixel size } Y, \mathrm{~m} \\
\text { Rozmiar piksela } Y, \mathrm{~m}\end{array}$ & 30.101 & 30.101 & 30.101 & 30.101 & 30.101 \\
\hline
\end{tabular}
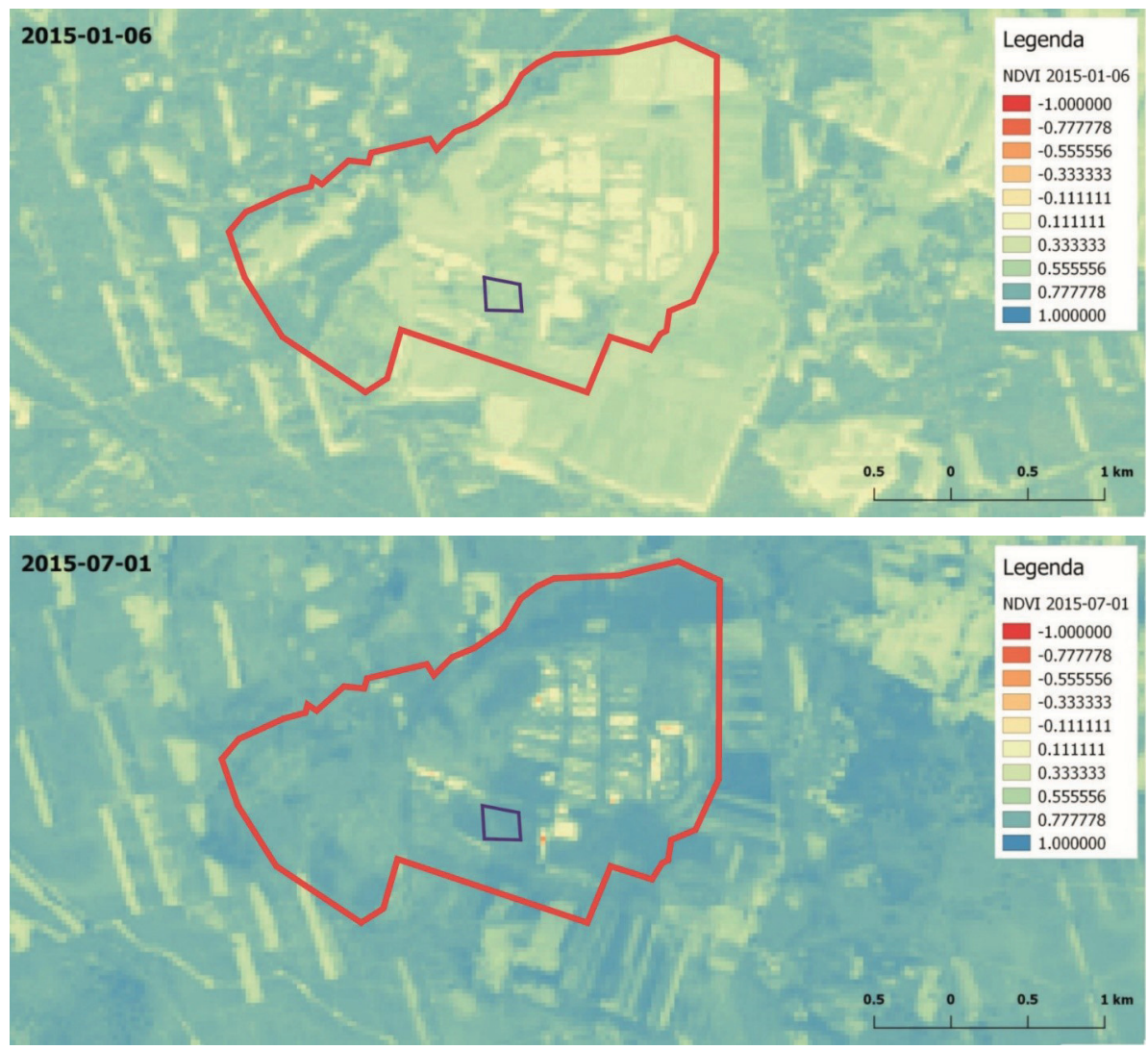

Fig. 3. An example of NDVI analysis - comparison for images of 2015-01-06 and 2015-07-01 (http, 2015a; http, 2015c)

Rys. 3. Przykład analizy NDVI - porównanie zobrazowań Landsat 8 OLI z 2015-01-06 oraz 2015- 07-01 (http, 2015a; http, 2015c) 
Czyż, P., Kowalik, A., Rutkowski, P. (2016). Application of Landsat satellite images for research on changes of vegetation conditions in the "Bagno Chlebowo" Natura 2000 site. Acta Sci. Pol. Silv. Colendar. Ratio Ind. Lignar., 15(3), 145-160. DOI: 10.17306/J. AFW.2016.3.17

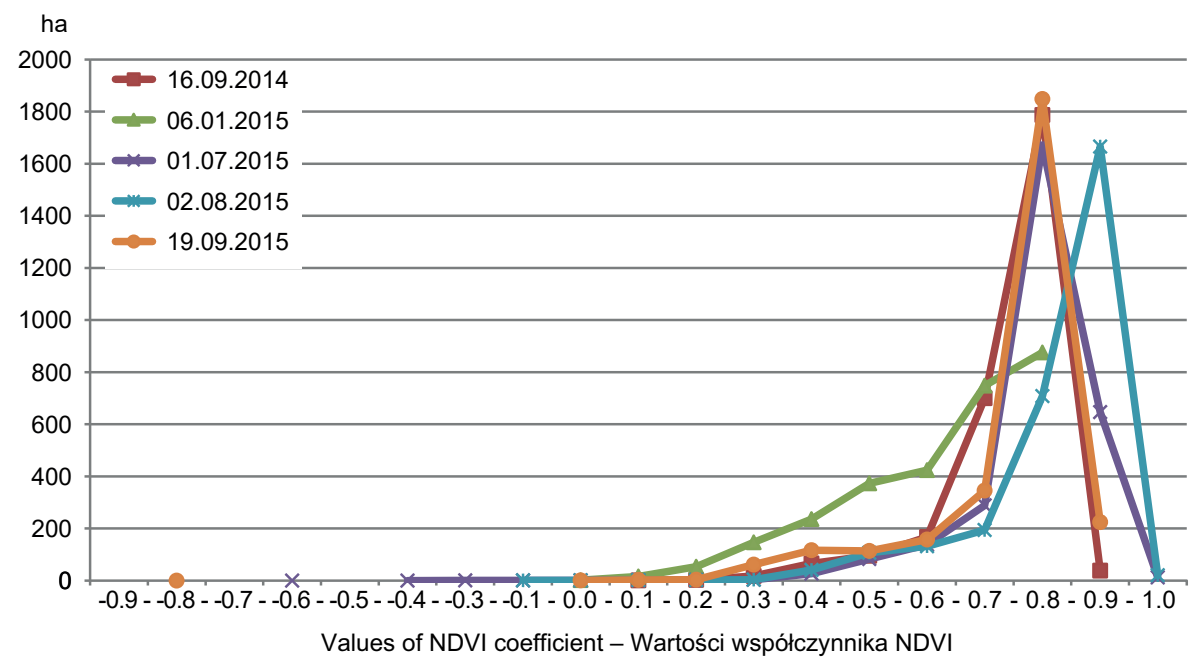

Fig. 4. Graph of NDVI index area summary for images selected for analysis. In order to make it more legible, the NDVI index values were grouped into classes (interval 0.1) Rys. 4. Wykres zestawienia powierzchni indeksu NDVI zobrazowań wybranych do analizy. W celu lepszej czytelności wartości indeksu NDVI pogrupowano w klasy (przedział 0,1)
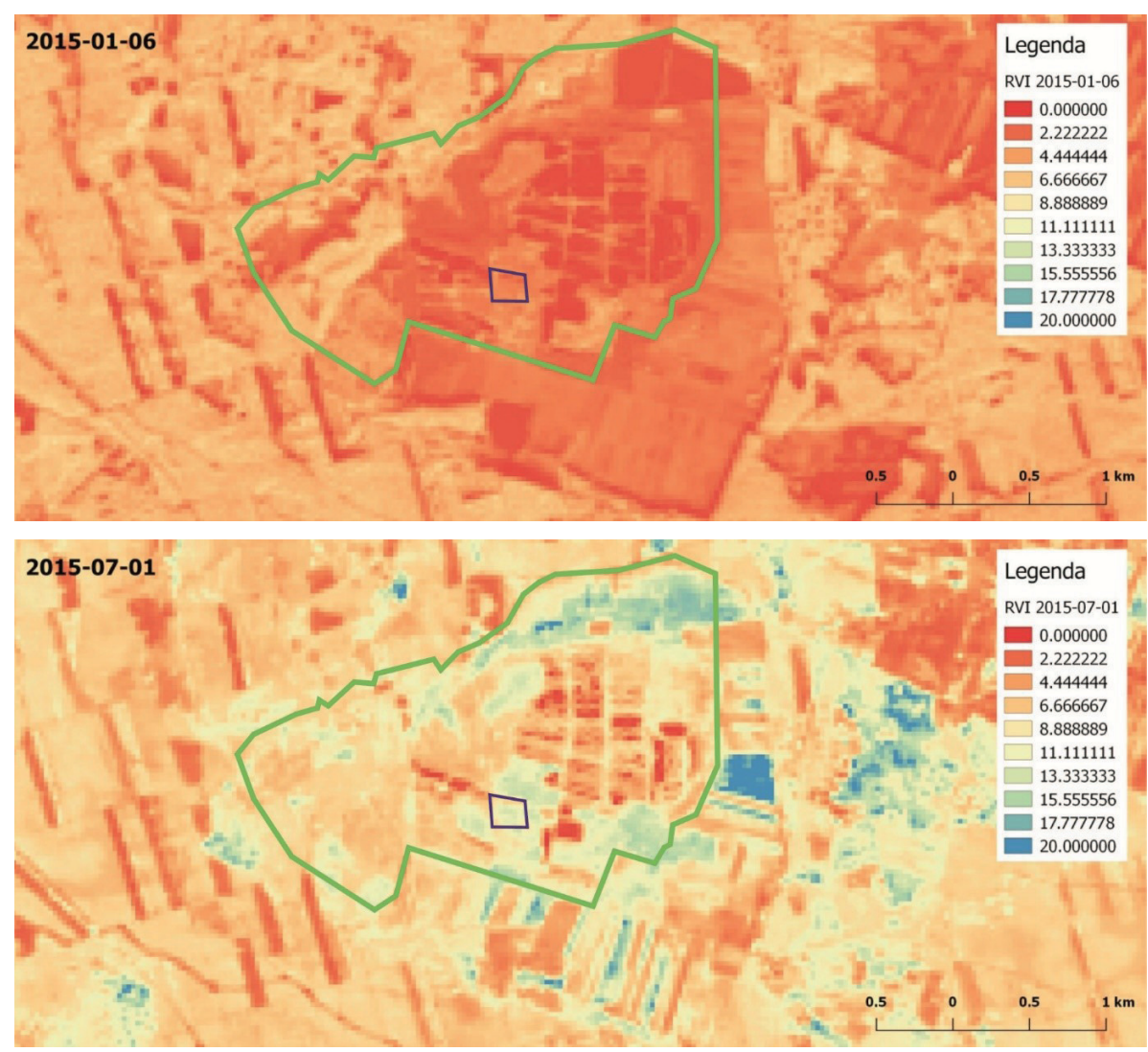

Fig. 5. Example of RVI analysis - comparison for images of 2015-01-06 and 2015-07-01 (http, 2015a; http, 2015c)

Rys. 5. Przykład analizy RVI - porównanie zobrazowań Landsat 8 OLI z 2015-01-06 oraz 2015-07-01 (http, 2015a; http, 2015c) 
Czyż, P., Kowalik, A., Rutkowski, P. (2016). Application of Landsat satellite images for research on changes of vegetation conditions in the "Bagno Chlebowo" Natura 2000 site. Acta Sci. Pol. Silv. Colendar. Ratio Ind. Lignar., 15(3), 145-160. DOI: 10.17306/J. AFW.2016.3.17

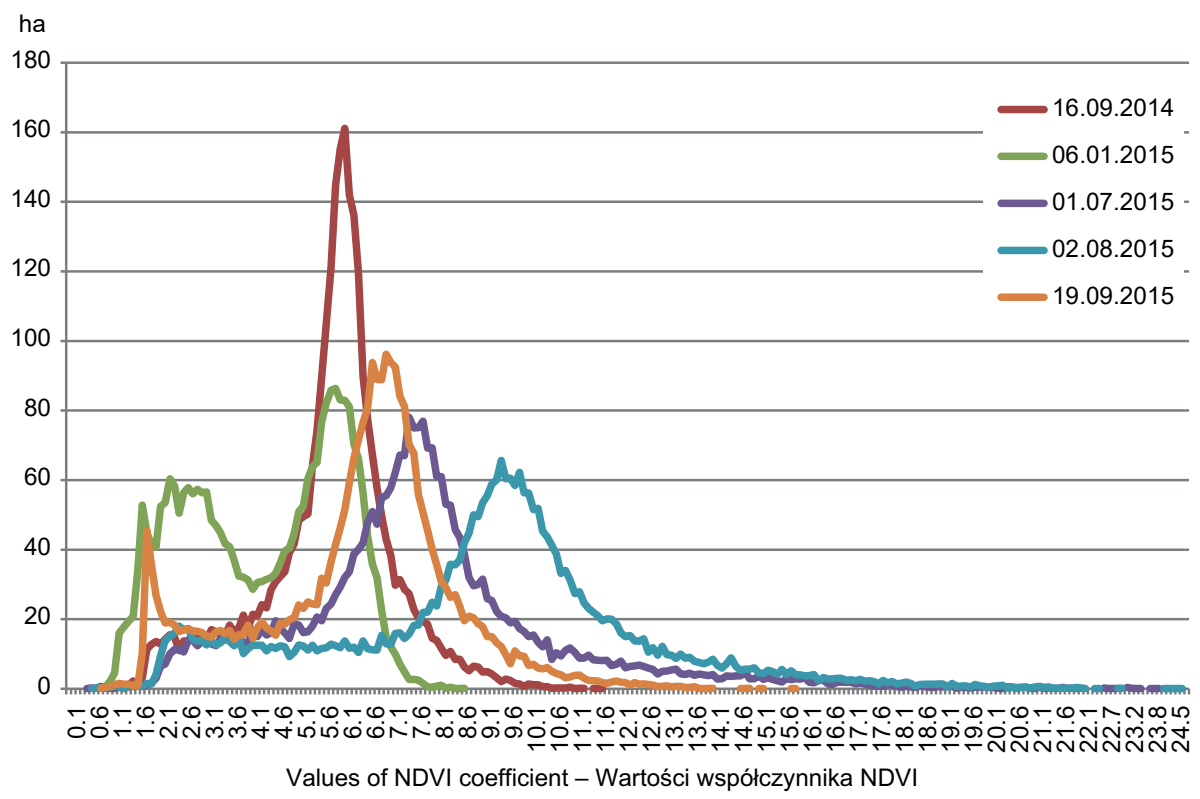

Fig. 6. Graph of RVI index area summary for images selected for analysis. In order to make it more legible, the RVI index values were grouped into classes (interval 0.1)

Rys. 6. Wykres zestawienia powierzchni indeksu RVI zobrazowań wybranych do analizy. W celu lepszej czytelności wartości indeksu RVI pogrupowano w klasy (przedział 0,1)
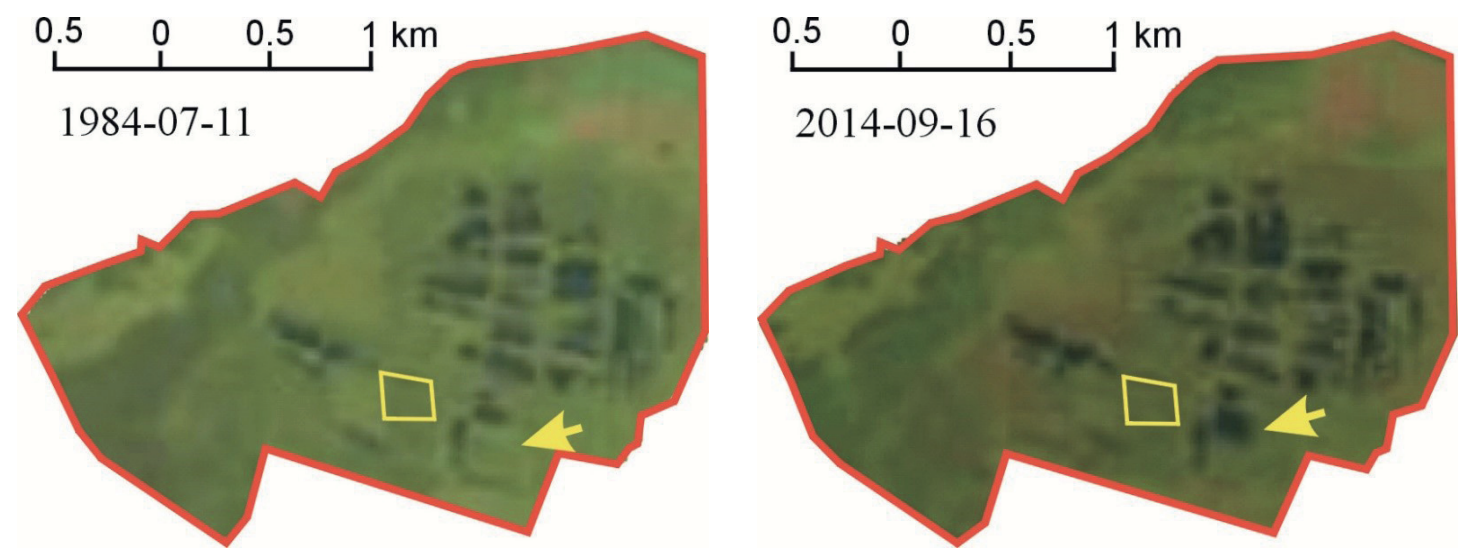

Fig. 7. Summary of images in visible light for 1984-07-11 and 2014-09-16 (http, 2015a). Areas with distinct changes caused by peat digging were marked with a yellow arrow

Rys. 7. Zestawienie zobrazowań w świetle widzialnym z 1984-07-11 (Landsat 4 TM) oraz 2014-09-16 (Landsat 8 OLI) (http, 2015a). Żółtą strzałką zaznaczono miejsce z wyraźnymi zmianami wywołanymi eksploatacją torfu 
Czyż, P., Kowalik, A., Rutkowski, P. (2016). Application of Landsat satellite images for research on changes of vegetation conditions in the "Bagno Chlebowo" Natura 2000 site. Acta Sci. Pol. Silv. Colendar. Ratio Ind. Lignar., 15(3), 145-160. DOI: 10.17306/J. AFW.2016.3.17
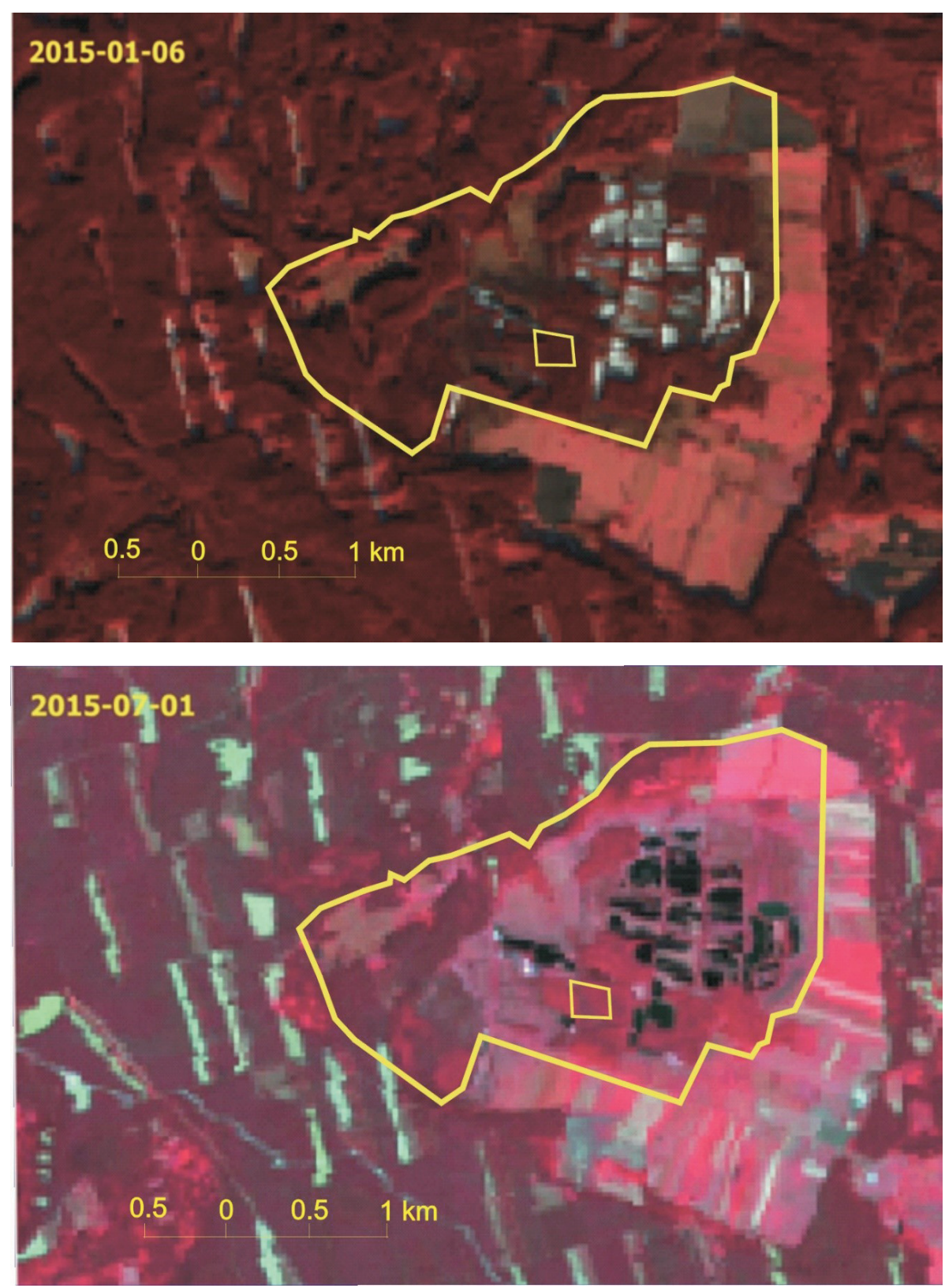

Fig. 8. Summary of exemplary images in NIR composition (unreal colours) dated 2015-01-06 and 2015-07-01 (http, 2015a; http, 2015c)

Rys. 8. Zestawienie przykładowych zobrazowań Landsat 8 OLI w kompozycji NIR (barwy nierzeczywiste) z 2015-01-06 oraz 2015-07-01 (http, 2015a; http, 2015c) 
Czyż, P., Kowalik, A., Rutkowski, P. (2016). Application of Landsat satellite images for research on changes of vegetation conditions in the "Bagno Chlebowo" Natura 2000 site. Acta Sci. Pol. Silv. Colendar. Ratio Ind. Lignar., 15(3), 145-160. DOI: 10.17306/J. AFW.2016.3.17

Table 2. Analysis results of RVI index for studied images

Tabela 2. Wyniki analizy współczynnika RVI dla badanych zobrazowań

\begin{tabular}{lccccc}
\hline \multirow{2}{*}{ Value - Wartość } & \multicolumn{5}{c}{ Image of - Zobrazowanie z dnia } \\
\cline { 2 - 5 } & $2014-09-16$ & $2015-01-06$ & $2015-07-01$ & $2015-08-02$ & $2015-09-19$ \\
\hline $\begin{array}{l}\text { Minimal value } \\
\text { Wartość minimalna }\end{array}$ & 1.023 & 0.836 & 0.267 & 0.585 & 0.166 \\
$\begin{array}{l}\text { Maximal value } \\
\text { Wartość maksymalna }\end{array}$ & 12.173 & 8.743 & 25.704 & 25.486 & 15.865 \\
$\begin{array}{l}\text { Mean value } \\
\text { Średnia wartość }\end{array}$ & 5.762 & 4.355 & 7.757 & 9.153 & 6.383 \\
$\begin{array}{l}\text { Standard deviation } \\
\text { Odchylenie standardowe }\end{array}$ & 1.437 & 1.685 & 2.895 & 3.388 & 2.126 \\
$\begin{array}{l}\text { Pixel size } X \text {, m } \\
\text { Rozmiar piksela } X \text {, m }\end{array}$ & 29.992 & 29.992 & 29.992 & 29.992 & 29.992 \\
$\begin{array}{l}\text { Pixel size } Y, \mathrm{~m} \\
\text { Rozmiar piksela } Y, \mathrm{~m}\end{array}$ & 30.101 & 30.101 & 30.101 & 30.101 & 30.101 \\
\hline
\end{tabular}

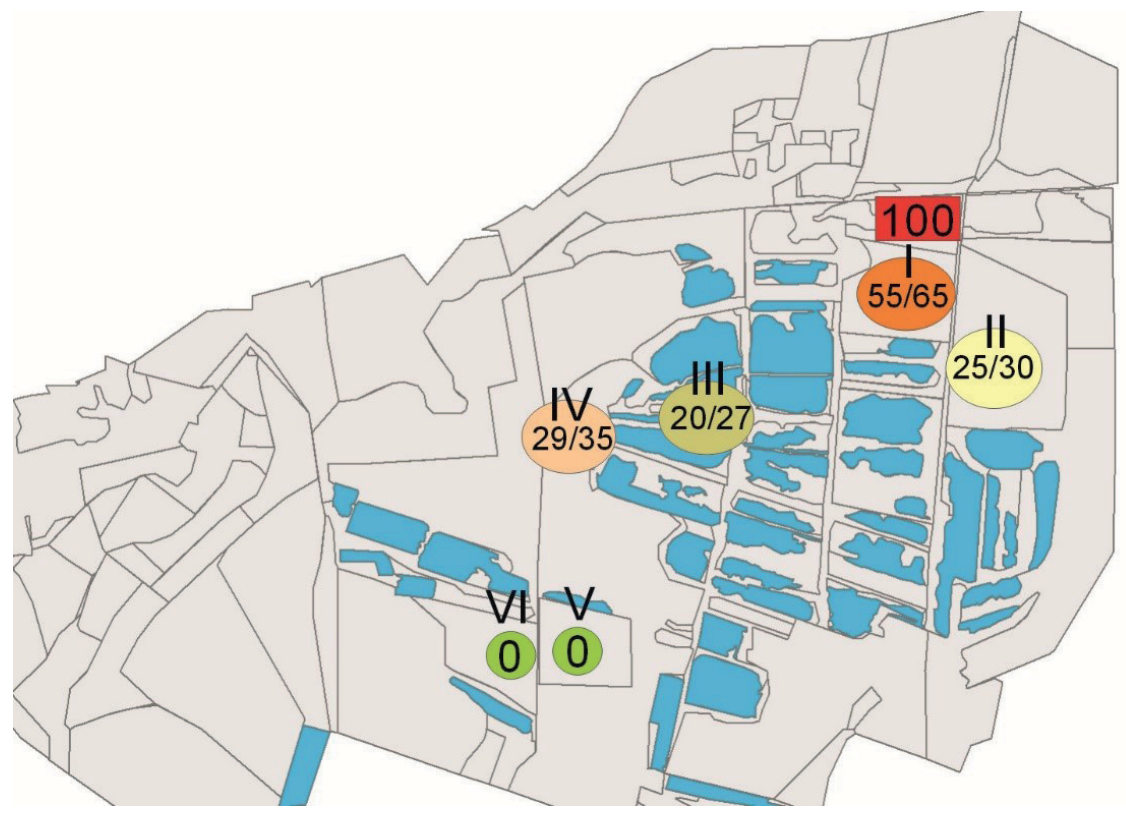

Fig. 9. Summary of percentage of dead trees in the areas I-VI. The values before the slash [\%] state the data of 2014, the ones after the slash - that of 2015. In areas V and VI no dead trees were recorded in the years 2014 and 2015. Also the additional area, in which all trees were dead in 2014 and 2015, was marked by red rectangle

Rys. 9. Zestawienie udziału procentowego drzew martwych na powierzchniach I-VI. Wartości przed ukośnikiem [\%] podają dane z 2014 roku, po ukośniku - z 2015 roku. Na powierzchniach V i VI w latach 2014 i 2015 nie odnotowano drzew martwych. Na rysunku zaznaczono też dodatkową powierzchnię, na której w 2014 i 2015 roku wszystkie drzewa były martwe (czerwony prostokąt) 
Czyż, P., Kowalik, A., Rutkowski, P. (2016). Application of Landsat satellite images for research on changes of vegetation conditions in the "Bagno Chlebowo" Natura 2000 site. Acta Sci. Pol. Silv. Colendar. Ratio Ind. Lignar., 15(3), 145-160. DOI: 10.17306/J. AFW.2016.3.17
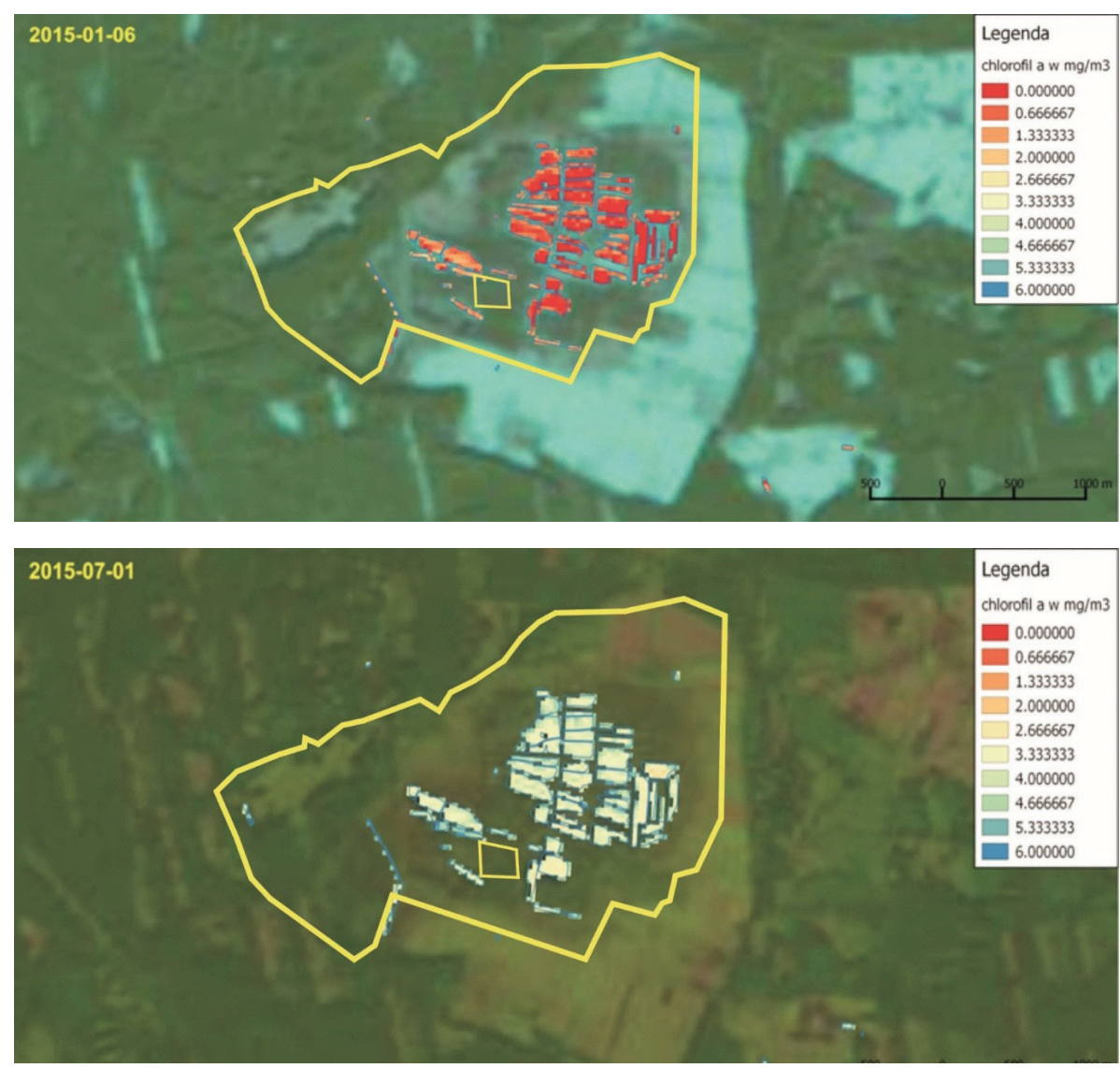

Fig. 10. Summary of exemplary analyses of chlorophyll "a" content in water according to satellite images dated 2015-01-06 and 2015-07-01 (http, 2015a; http, 2015c)

Rys. 10. Zestawienie przykładowych analiz zawartości chlorofilu „a” w wodzie na podstawie zobrazowań satelitarnych Landsat 8 OLI z 2015-01-06 oraz 2015-07-01 (http, 2015a; http, 2015c)

Table 3. Results of analysis of chlorophyll "a" in water for investigated images

Tabela 3. Wyniki analizy chlorofilu ,a” w wodzie dla badanych zobrazowań

\begin{tabular}{lccccc}
\hline \multicolumn{1}{c}{$\begin{array}{c}\text { Value }- \text { Wartość } \\
\mathrm{mg} / \mathrm{m}^{3}\end{array}$} & \multicolumn{5}{c}{ Image of - Zobrazowanie z dnia } \\
\cline { 2 - 5 } & $2014-09-16$ & $2015-01-06$ & $2015-07-01$ & $2015-08-02$ & $2015-09-19$ \\
\hline $\begin{array}{l}\text { Minimal value } \\
\text { Wartość minimalna }\end{array}$ & 1.366 & 0.000 & 2.293 & 0.230 & 0.000 \\
$\begin{array}{l}\text { Maximal value } \\
\text { Wartość maksymalna }\end{array}$ & 4.458 & 2.134 & 5.997 & 5.113 & 4.695 \\
$\begin{array}{l}\text { Mean value } \\
\text { Średnia wartość }\end{array}$ & 2.983 & 0.431 & 3.746 & 3.491 & 2.823 \\
$\begin{array}{l}\text { Standard deviation } \\
\text { Odchylenie standardowe }\end{array}$ & 0.270 & 0.789 & 0.591 & 0.487 & 0.350 \\
\hline
\end{tabular}


Czyż, P., Kowalik, A., Rutkowski, P. (2016). Application of Landsat satellite images for research on changes of vegetation conditions in the "Bagno Chlebowo" Natura 2000 site. Acta Sci. Pol. Silv. Colendar. Ratio Ind. Lignar., 15(3), 145-160. DOI: 10.17306/J. AFW.2016.3.17

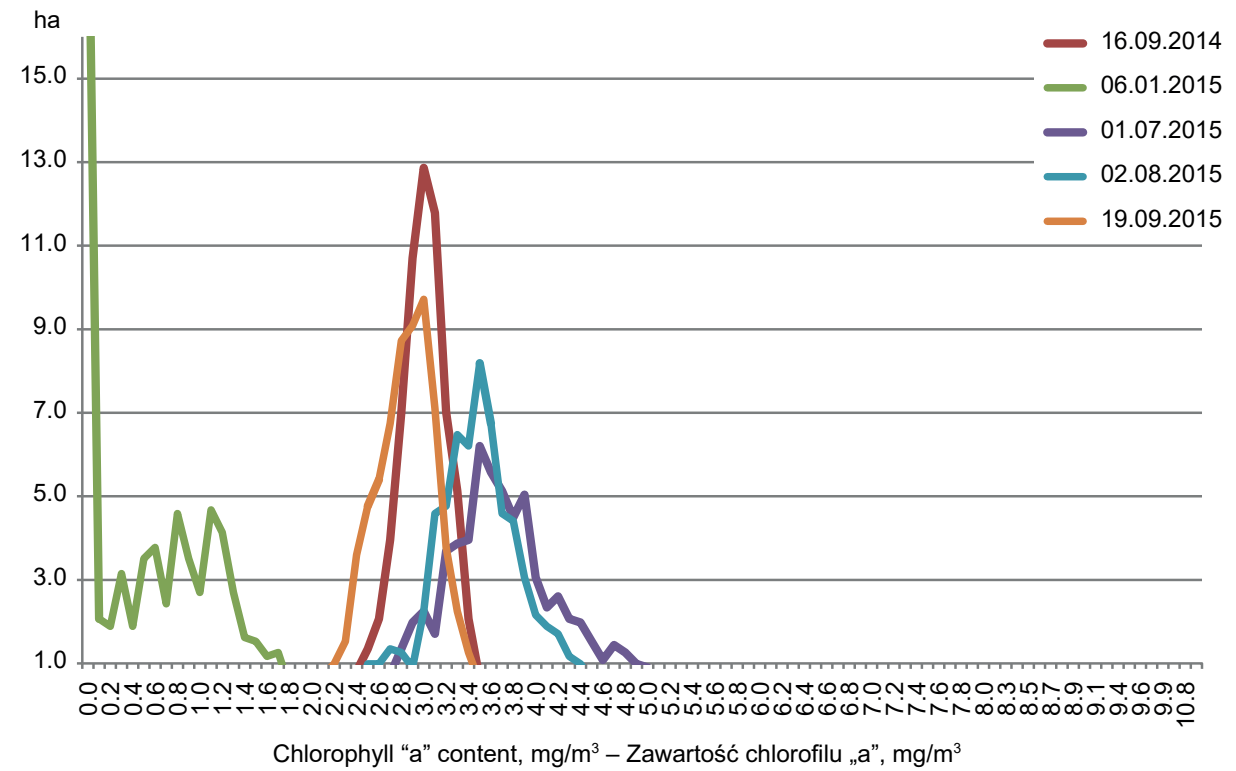

Fig. 11. Chart showing the dependence between chlorophyll "a" content in water and the water area

Rys. 11. Wykres przedstawiający zależność między zawartością chlorofilu „a” w wodzie a powierzchnią wód

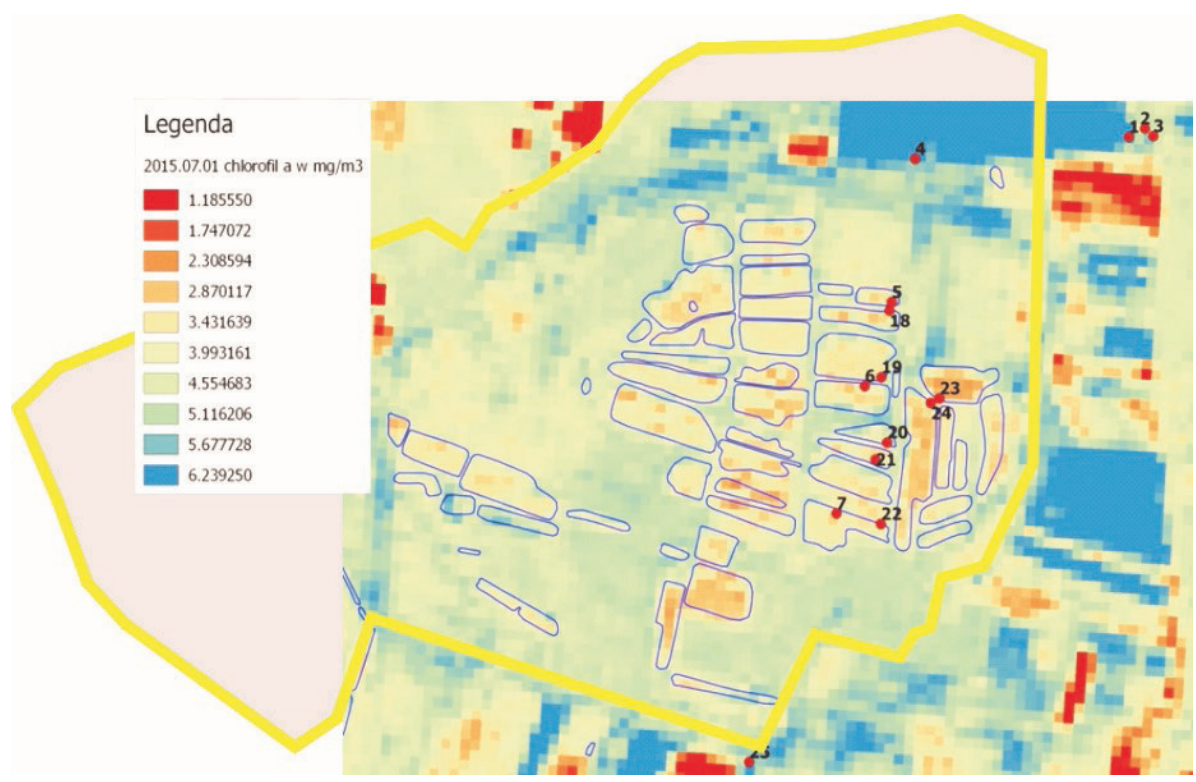

Fig. 12. Sampling areas for analyses dated 2015-05-03 and 2015-07-18 against Landsat analysis for the composition of 2015-07-01 (the numbers on the map are numbers of measurement points)

Rys. 12. Miejsca poboru próbek wody (oznaczone numerami 1-7, 18-25) z 3 maja oraz 18 lipca 2015 roku, na tle analizy danych z satelity Landsat 8, dla kompozycji z 1 lipca 2015 roku 
Czyż, P., Kowalik, A., Rutkowski, P. (2016). Application of Landsat satellite images for research on changes of vegetation conditions in the "Bagno Chlebowo" Natura 2000 site. Acta Sci. Pol. Silv. Colendar. Ratio Ind. Lignar., 15(3), 145-160. DOI: 10.17306/J. AFW.2016.3.17

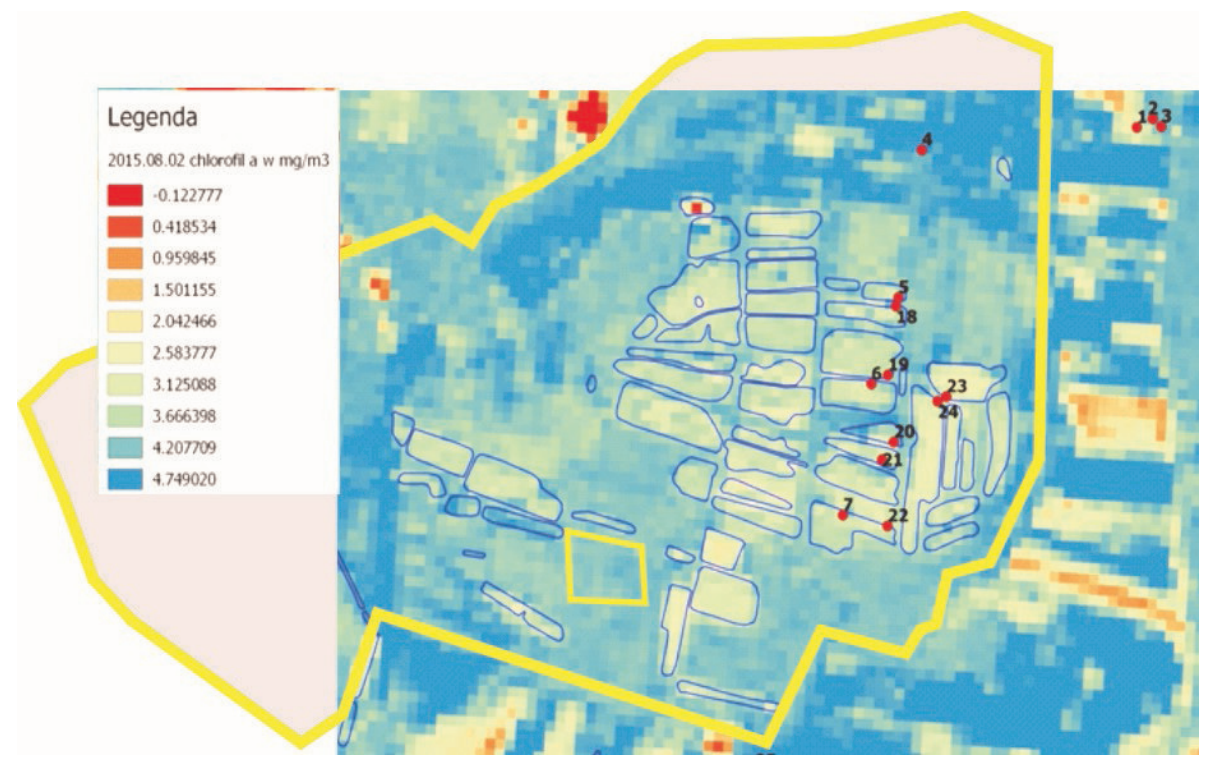

Fig. 13. Sampling areas for analyses dated 2015-05-03 and 2015-07-18 against Landsat analysis for the composition of 2015-08-02 (the numbers on the map are numbers of measurement points)

Rys. 13. Miejsca poboru próbek wody (oznaczone numerami 1-7, 18-25) z 3 maja oraz 18 lipca 2015 roku, na tle analizy danych z satelity Landsat 8, dla kompozycji z 2 sierpnia 2015 roku

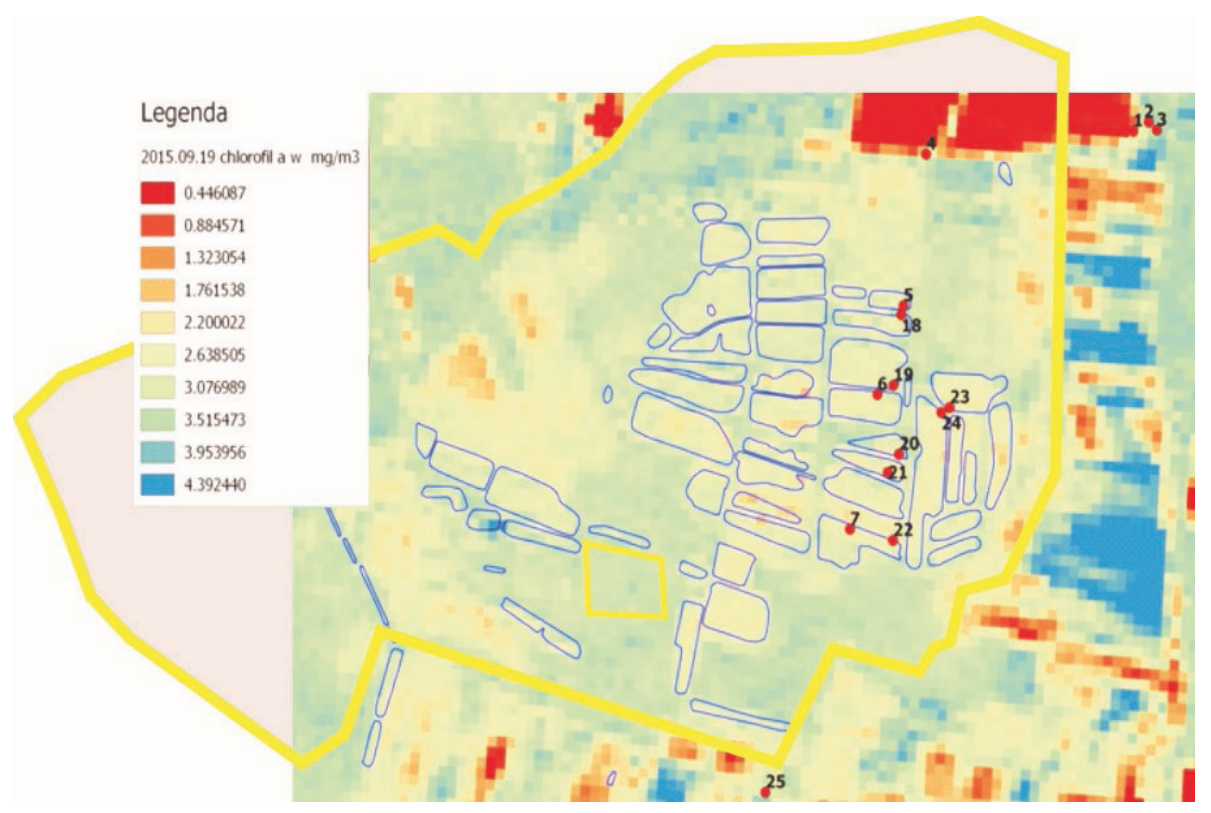

Fig. 14. Sampling areas for analyses dated 2015-05-03 and 2015-07-18 against Landsat analysis for the composition of 2015-09-19 (the numbers on the map are numbers of measurement points)

Rys. 14. Miejsca poboru próbek wody (oznaczone numerami 1-7, 18-25) z 3 maja oraz 18 lipca 2015 roku, na tle analizy danych z satelity Landsat 8, dla kompozycji z 19 września 2015 roku 
Czyż, P., Kowalik, A., Rutkowski, P. (2016). Application of Landsat satellite images for research on changes of vegetation conditions in the "Bagno Chlebowo" Natura 2000 site. Acta Sci. Pol. Silv. Colendar. Ratio Ind. Lignar., 15(3), 145-160. DOI: 10.17306/J. AFW.2016.3.17

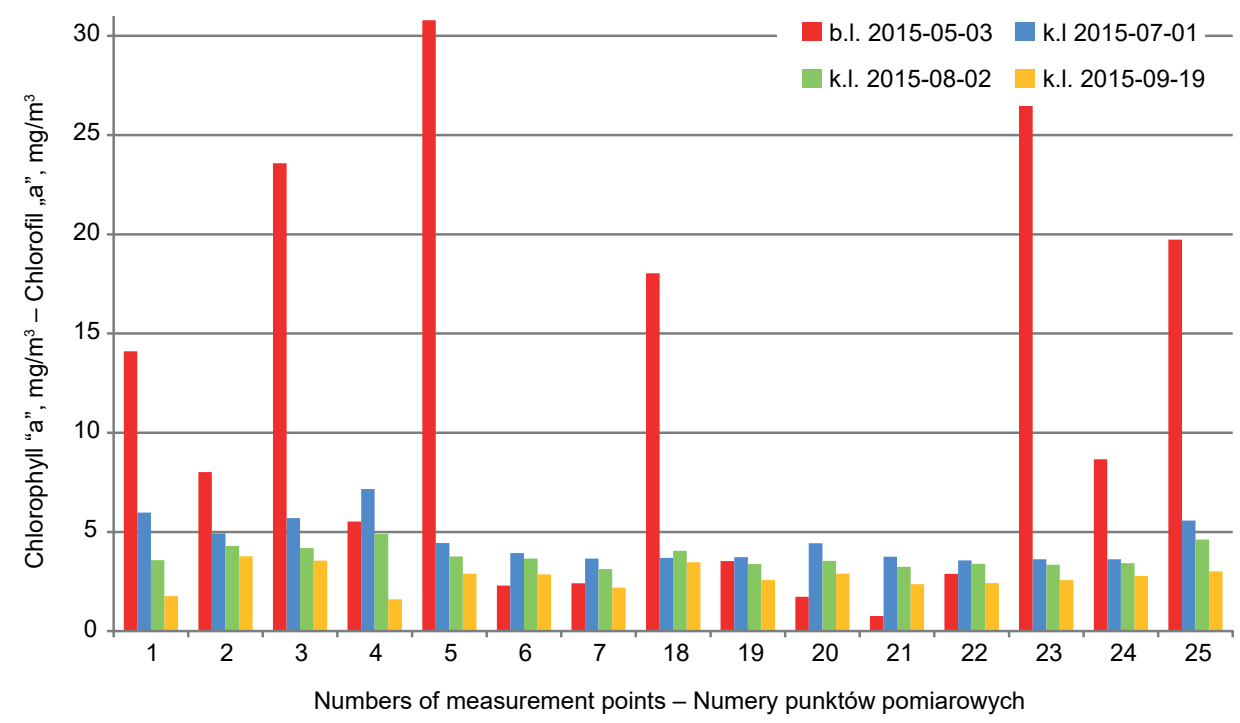

Fig. 15. Comparison of field data of 2015-05-03 with results of Landsat analysis for the composition of the days: 2015-07-01, 2015-08-02 and 2015-09-19: b.1. - laboratory tests, k.l. - Landsat composition

Rys. 15. Porównanie danych terenowych z 2015-05-03 z wynikami analizy Landsat 8 OLI dla kompozycji z dni: 2015-07-01, 2015-08-02 oraz 2015-09-19: b.1. - badania laboratoryjne, k.1. - kompozycja Landsat

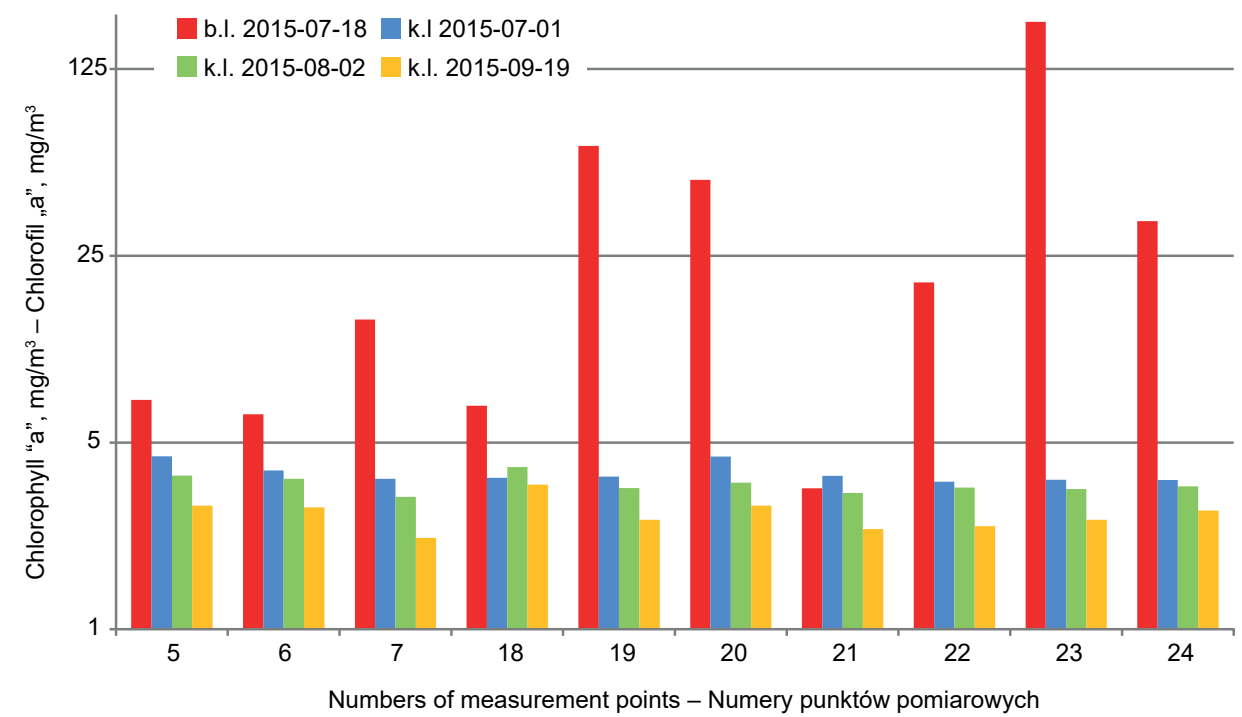

Fig. 16. Comparison of field data of 2015-07-18 with results of Landsat analysis for the composition of the days: 2015-07-01, 2015-08-02 and 2015-09-19: b.1. - laboratory tests, k.l. - Landsat composition

Rys. 16. Porównanie danych terenowych z 2015-07-18 z wynikami analizy Landsat 8 OLI dla kompozycji z dni: 2015-07-01, 2015-08-02 oraz 2015-09-19: b.1. - badania laboratoryjne, k.1. - kompozycja Landsat 
Czyż, P., Kowalik, A., Rutkowski, P. (2016). Application of Landsat satellite images for research on changes of vegetation conditions in the "Bagno Chlebowo" Natura 2000 site. Acta Sci. Pol. Silv. Colendar. Ratio Ind. Lignar., 15(3), 145-160. DOI: 10.17306/J. AFW.2016.3.17

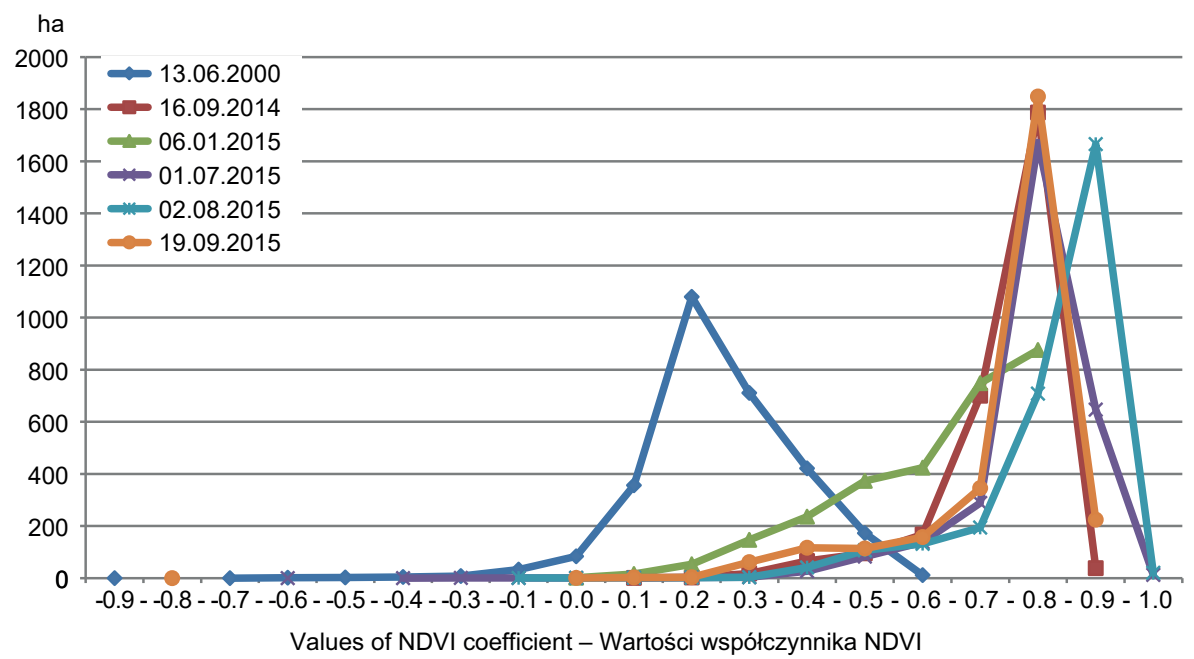

Fig. 17. Chart of summary of NDVI index area for images selected for analysis in view of the data of 13.06.2000, being cross-reference to Figure 4

Rys. 17. Wykres zestawienia powierzchni indeksu NDVI wybranych do analizy zobrazowań z uwzględnieniem danych z 13 czerwca 2000 roku, będący odnośnikiem do rysunku 4

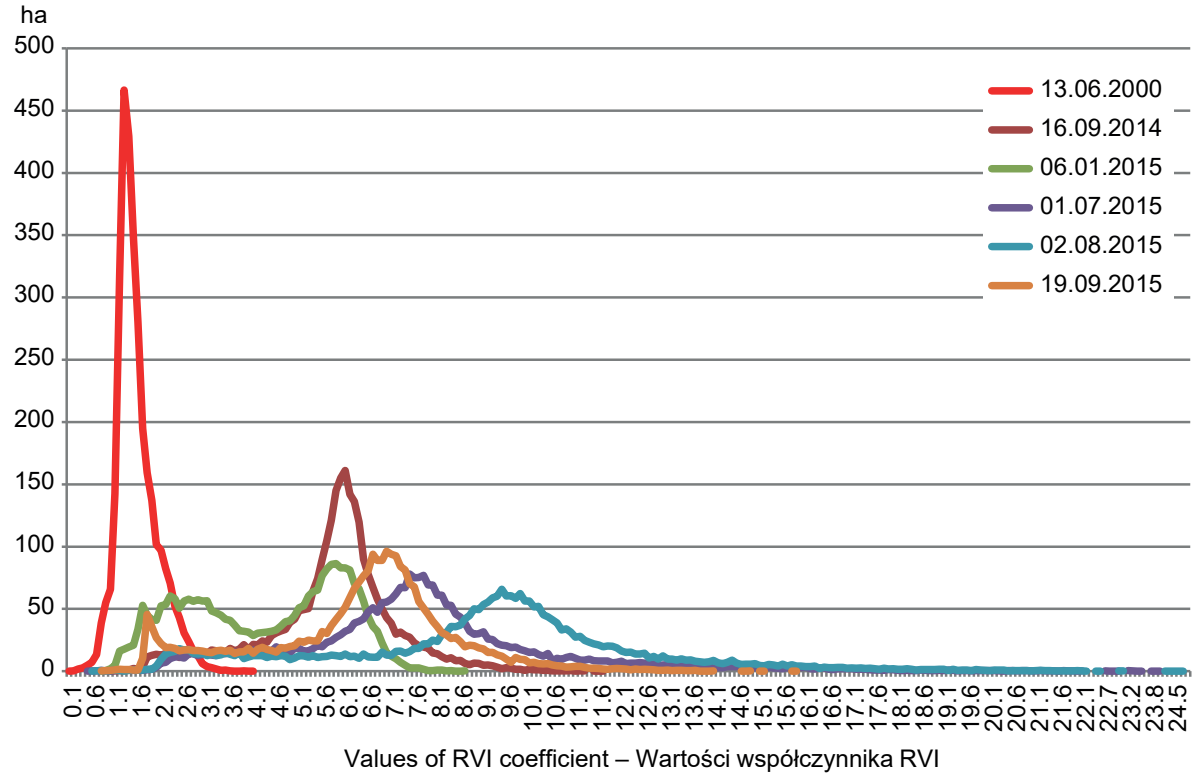

Fig. 18. Chart of summary of RVI index area for images selected for analysis in view of the data of 13.06.2000, being cross-reference to Figure 6

Rys. 18. Wykres zestawienia powierzchni indeksu RVI dla wybranych do analizy zobrazowań z uwzględnieniem danych z 13 czerwca 2000 roku, będący odnośnikiem do rysunku 6 
which is a natural consequence of plants winter rest period. Plant cover showed on Figure 3 can be divided into three distinct groups:

- pine forests, with similar winter and summervalues of NDVI (values near to 0.7 ), which vast complex extends mainly beyond the boundaries of "Bagno Chlebowo" (within the area of occupying only western part of Natura 2000 site)

- bogs, meadows and forests on peat, which show a clear winter rest period (values near 0.2), passing lush growth phase in the summer (when the index achieve maximum values). Altered state of forests on peat, compared to the pine forests outside the Natura 2000 site, may indicate a growing share of birch (Betula pendula and B. pubescens) in these communities and equally transition of the of $\mathrm{Vacci}$ nio uliginosi-Pinetum into Vaccinio uliginosi-Betuletum pubescentis plant community

- the peat pits filled with water, which in winter have aligned state with the index close to 0.0 , differentiating on summer, when the small patches reaches NDVI value $(-0.7)$, but most of reservoirs show in Figure 3 mosaic of colors with values from 0.0 to 0.4 . The mosaic of colors correspond to the variability of cover of water vegetation - depending on the reservoir - of the genus Spirodela or Lemna.

\section{Analysis of RVI index}

Values of RVI index ranged from 0.166 to 25.704 . They are summarized in Table 2, while the results for different measuring seasons in Figure 5. RVI index in an even stronger way highlights seasonal differences between winter and summer. In January 2015 RVI values ranged from 0.836 to 8.743 , the summer corresponding to above mentioned extreme values. Obtained results of RVI index confirm the merits of dividing the vegetation of Natura 2000 site and its neighbourhood on 3 above mentioned NDVI groups, with a similar interpretation. It seems, however, that the RVI index, in a better way highlights the presence of pine (Pinus sylvestris), which - apart from the forests outside the Natura 2000 site - spreads in the western part of "Bagno Chlebowo" Natura 2000 site and surrounds the peat pits. In the neighbourhood of the "Bagno Chlebowo" nature reserve and to the east, to the border of Site, it seems that the grater share achieves the birch (the RVI values in July 2015 close to 15 ).

\section{Analysis in visible light}

The analysis of images in visible light available from 1984 points to increasing anthropopressure related to intensification of forest management, arable farming and peat digging. A visual example of these phenomena is shown in Figure 7.

The usefulness of such a type of data increases with the improving of image quality, which is apparent even in the comparison of images of 1984 and 2014, however the quality is definitely worse than that of the contemporary orthophotomaps.

\section{Analysis in unnatural colours (NIR - infrared composition)}

The analysis of images in unnatural colours (NIR infrared composition) points, especially in winter, to tree stands apart from the other types of vegetation, equally differentiating the health state of the forests in summer (Fig. 8). Visible summer differences could be the result of the forest species composition, as well as in forest health. In the western part of the Natura 2000 well visible are the pine stands, with the health similar to the forests growing beyond the borders of Natura 2000 site, while in "Bagno Chlebowo" nature reserve and in its neighbourhood a lighter colour distinguishes pine and birch stands (Vaccinio uliginosi-Betuletum pubescentis).

\section{Analysis of chlorophyll "a" content in water}

The primary algorithm was used for the analysis of areas covered with large water reservoirs (Osińska-Skotak, 2009). Here, due to the small area of reservoirs, in the analysis of the image of 2015-01-06 negative values appeared, which, for the needs of the analysis, were replaced by the value " 0 " meaning, in this specific case, the shortage of chlorophyll. All data were presented in Table 3.

\section{DISCUSSION}

The quality of satellite images and the possibility of their utilization are increasingly larger. A continuous comparison of data collected by satellites with the results of ground observations and their interpretation serve the improvement of this quality. Such a situation was encountered at this study too, which revealed errors in the data collected by Landsat 7 satellite in 
Czyż, P., Kowalik, A., Rutkowski, P. (2016). Application of Landsat satellite images for research on changes of vegetation conditions in the "Bagno Chlebowo" Natura 2000 site. Acta Sci. Pol. Silv. Colendar. Ratio Ind. Lignar., 15(3), 145-160. DOI: 10.17306/J. AFW.2016.3.17

2000. Taking into account the data of 13 June 2000, the charts for NDVI index presented in Figure 4 and RVI index shown in Figure 6 would look like in Figures 16 and 17.

From this data sheet it would arise that the vegetation exhibited a higher activity in January (2015) than in June (2000), and this result would be difficult to defend.

Information on operating errors of Landsat 7 satellite in the described period is also confirmed by other authors (Walawender et al., 2011).

Verification of data can also have importance for ground observations. A good example are the results of chlorophyll "a" content in water in the area of "Bagno Chlebowo". In this case taking samples for laboratory analyses from a single point of the reservoir may be responsible for the error, as it does not correspond to average chlorophyll "a" content in the reservoir in all.

In this respect satellite data can be more credible, although it may depend on the size of the reservoir. For it is worth remembering that satellite data applied for testing of chlorophyll "a" content in surface waters once related to seas and oceans only. And now they also refer to large areas of freshwater reservoirs. One reason for the differences between results of laboratory analyses and satellite data for chlorophyll "a" content in the study may be the fact that the investigated pits formed after peat digging are not very large. The trees growing in the surroundings of the reservoirs could have disturbed the transparency of the image by casting a shadow on the water sheet. However such observations confirm the research necessity this study was dedicated to.

\section{CONCLUSIONS}

Each of satellite images comprising data concerning the NDVI index (Normalized Difference Vegetation Index), RVI index (Ratio Vegetation Index), analysis in visible light, near infrared analysis (NIR) and chlorophyll "a" content in water have different significance. Regarding the changes undergoing in the area of "Bagno Chlebowo", comprising merely peat digging, images in visible light are sufficient, although the quality of satellite images gives way to the orthophotomap, which has a higher resolution. However, an increasing area of pits formed after peat digging was demonstrated, and thereby a decreasing share of valuable habitats such as peat bogs.

An analysis of NDVI index showed relative stability of the photosynthesis process in pine stands on mineral soil growing outside the Natura 2000 area, both in the winter and summer seasons (NDVI ca. 0.78) and significant changes undergoing in tree stands growing in the area "Bagno Chlebowo" on peat, where NDVI in the winter season fluctuates around 0.55 , reaching the value of almost 1.00 in summer. A similar reaction of the tree stands is confirmed by the analysis of RVI index, the values of which are similar for pine stands on mineral soils outside the area, both in winter and summer (in the range 6-8), whereas tree stands growing on peats have a discrepancy ranging from $6-8$ in January, to $13-15$ in summer.

For the analysis of the health state of tree stands images in near infrared (NIR) seem to be useful, showing convergence with the percentage share of dead trees in the investigated tree stands.

With regard to images showing chlorophyll "a" content in waters of the area "Bagno Chlebowo", a significant divergence from the results of laboratory analyses was revealed. These divergences may be affected by differences resulting from the water sampling place, differences in dates of image taking and water sampling, that can be significant even in case of several days intervals, especially in summer, or shadow cast by trees surrounding the water reservoirs.

\section{REFERENCES}

Apis (2012). Ekspertyza siedlisk przyrodniczych na potrzeby projektu planu zadań ochronnych dla obszaru Natura 2000 Bagno Chlebowo PLH300016 [Expert opinion on natural habitats for the needs of the project of protective tasks for the area Natura 2000 Bagno Chlebowo PLH300016]. Potasze. Unpublished manuscript. Regionalna Dyrekcja Ochrony Środowiska, Poznań [in Polish].

Apis (2015). Bagno Chlebowo PLH 300016 wyniki badań dotyczących genezy nadmiernego uwodnienia siedlisk przyrodniczych 6410 i 91D0 oraz eutrofizacji siedliska 91D0. Cz. 2 (za okres od maja 2015 r. do października 2015 r.) [Bagno Chlebowo PLH 300016 research results concerning genesis of excessive hydration of natural habitats $6410 \& 91 D 0$ and eutrophication of habitat 91D0. Cz. 2 (for the period from May 2015 to October 
Czyż, P., Kowalik, A., Rutkowski, P. (2016). Application of Landsat satellite images for research on changes of vegetation conditions in the "Bagno Chlebowo" Natura 2000 site. Acta Sci. Pol. Silv. Colendar. Ratio Ind. Lignar., 15(3), 145-160. DOI: 10.17306/J. AFW.2016.3.17

2015)]. Potasze. Unpublished manuscript. Regionalna Dyrekcja Ochrony Środowiska, Poznań [in Polish].

Campbell, J. B., Wynne, R. H. (2011). Introduction to remote sensing. Fifth edition. New York, USA: Guilford Press.

Ghezzi, P., Giardino, C., Pepe, M., Zilioli, E. (1998). Report on the 2nd Salmon joint meeting (pp. 10-11). Venice.

Griffth, J. A., Martinko, E. A., Whistler, J. L., Price, K. P. (2002). Interrelationships among landscapes, NDVI, and stream water quality in the U.S. Central Plains. Ecol. Applic., 6(12), 1702-1718.

http (2015a). Retrieved December 25, 2015, from http:// landsat.usgs.gov

http (2015b). Retrieved December 25, 2015, from http:// fromgistors.blogspot.com/p/semi-automatic-classification-plugin.html

http (2015c). Retrieved December 25, 2015, from http:// www.igf.fuw.edu.pl/ kasztel/PDF/Tel.pdf

Jones, H. G., Vaughan, R. A. (2010). Remote sensing of vegetation. Principles, techniques, and applications. Oxford.

Osińska-Skotak, K. (2009). Możliwości teledetekcyjnego monitorowania zawartości chlorofilu-a w wodach śródlądowych [Possibilities of remote sensing of chlorophyll-a content in inland waters]. Teledetekcja Środowiska [dawniej Fotointerpretacja w Geografii], 42, 60-68 [in Polish].

Ostapowicz, K. (2012). Detekcja zmian pokrycia terenu z wykorzystaniem obrazów satelitarnych. In GIS - teledetekcja środowiska (pp. 21-30). Poznań [in Polish].

Piekarski, P., Zwoliński, Z. (2012). Dywersyfikacja odbicia spektralnego i wskaźników wegetacyjnych dla drzewostanów sosnowych i bukowych. Nizina Szczecińska. In GIS - teledetekcja środowiska (pp. 31-41). Poznań [in Polish].

SDF (2013). Standardowy formularz danych dla obszaru Natura 2000 „Bagno Chlebowo” [Standard data form for the area Natura 2000 "Bagno Chlebowo"]. Retrieved April 20, 2016, from natura2000.gdos.gov.pl/datafiles/ download/PLH300016/sdf [in Polish].

Walawender, J., Hajto, M., Iwaniuk, P. (2011). Zastosowanie algorytmu ,pojedynczego okna” do opracowania map temperatury powierzchni ziemi na podstawie danych satelitarnych Landsat [Application of the ,singlechannel" algorithm for mapping land surface temperature based on Landsat satellite data]. Rocz. Geomat., 9, 4(48), 140-150 [in Polish].

Wang, J., Rich, P. M., Price, K. P., Kettle, W. D. (2004). Relations between NDVI and tree productivity in the central Great Plains. Int. J. Remote Sens., 16(25), 3127-3138.

Wełnicka, A. Czyż, P., Rutkowski, P. (2015). Bagno Chlebowo na tle źródeł historycznych [Bagno Chlebowo against the background of historical sources]. Stud. Mater. Ośr. Kult. Leśn., 14, 317-328 [in Polish].

Williams, M., Rastetter, E. B., Shaver, G. R., Hobbie, J. E., Carpino, E., Kwiatkowski, B. L. (2001). Primary production of an Arctic Watershed: an uncertainty analysis. Ecol. Applic., 6(11), 1800-1816.

Wiśniewska, E. (2013). Wprowadzenie do analiz teledetekcyjnych obszarów leśnych. In K. Okła (Ed.), Geomatyka w Lasach Państwowych. Cz. 2. Poradnik praktyczny (pp. 152-167). Warszawa: CILP [in Polish].

\title{
ZASTOSOWANIE ZOBRAZOWAŃ SATELITARNYCH LANDSAT DO BADAŃ NAD ZMIANAMI STANU ROŚLINNOŚCI W OBSZARZE NATURA 2000 „BAGNO CHLEBOWO”
}

\begin{abstract}
ABSTRAKT
W pracy przedstawiono zróżnicowanie roślinności obszaru Natura 2000 „Bagno Chlebowo” na podstawie analizy zdjęć satelitarnych Landsat 7 i 8. Opracowania teledetekcyjne obejmowały analizy: wskaźników wegetacyjnych NDVI, RVI, zawartości chlorofilu-a w wodzie, zmian pokrycia roślinności w kompozycjach barw nierzeczywistych i w świetle widzialnym. Analizę zobrazowań odniesiono do badań terenowych.
\end{abstract}

Słowa kluczowe: NDVI, RVI, chlorofil „,a”, teledetekcja 